\title{
LIFE ORIENTATION TEACHERS' CAREER DEVELOPMENT NEEDS IN GAUTENG: ARE WE MISSING THE BOAT?
}

\author{
B. M. Diale \\ Department of Educational Psychology \\ University of Johannesburg \\ Johannesburg, South Africa \\ e-mail: tumid@uj.ac.za
}

\section{ABSTRACT}

The constant changes in the Life Orientation (LO) curriculum in the past two decades has left LO teachers feeling overwhelmed by the complex nature of the subject, thus necessitating an urgent need for their development and enrichment. However, this has become a mammoth task, as indicated in the few studies that have explored LO teachers' career development needs. This article seeks to narrow this gap by addressing the career development needs of LO teachers in the Gauteng Province with the view of enabling them to effectively implement the Life Orientation curriculum. This article is based on a study that employed a qualitative design, which comprised individual and focus group interviews to elicit responses from a purposively selected group of LO teachers. Themes that emerged from the data analysis are, the need for formal training, the need for subject and content knowledge development, the need for support from key stakeholders, the need for resources, and the need for stability in the LO subject. These needs are embedded within the activity theory (AT). The results of this study indicate that an urgency exists to address the LO teachers' career needs in the constantly changing world of work.

Key words: Cultural Historical Activity theory, career development, Life Orientation, LO teachers' needs, professional development.

\section{INTRODUCTION}

This article derives from findings of a more comprehensive study and focusses on the career development needs of LO teachers in the Gauteng Province. Whilst engaging with LO teachers who were furthering their studies at a higher education institution in Gauteng as part of their career development journey, I came across a myriad of challenges that illustrated their feelings of being ill-equipped to teach the subject. The situation was exacerbated by among other things, the vicissitude in the socio-economic realm that was not part of the curriculum but yet LO teachers could not ignore those issues. The immense outcry of unavailable career development for these teachers couldn't be silenced. As an academic, bequeathed with the responsibility of further developing these teachers, I had asked myself, 'Are we missing the boat in the in-service 
training these teachers?' I found this to be a complex issue to tackle, hence the endeavour to unravel the career development needs of LO teachers in the Gauteng Province. In essence, this article argues that addressing LO teachers' career development needs is crucial, not only for them to effectively implement the curriculum, but to also enable them to address the social ills that accompany learners into the school and classroom. LO teachers are thus required to be well versed in addressing the daily and topical issues faced by learners; such as HIV and AIDS, youth unemployment, poverty, crime, drug and substance abuse, child and youth headed households, and school violence; in turn, these issues affect their learning and development (Diale, Pillay and Fritz 2014). If LO has to have the desired impact that inculcates a culture of respect and sets in motion social justice, peace, hope, care, and transformation for learners, parents, teachers and the larger community (Mahlomaholo 2012), there needs to be a major paradigm shift in the way LO teachers' career development needs are viewed and the way the LO curriculum is realised in South African classrooms. In addition, if LO teachers are expected to address the current national priorities as influenced by global developments (Singh 2011), their career development needs can no longer be ignored.

During their career lives in education, LO teachers are bestowed with a diverse population of learners in their classrooms. Some of these learners are easy to manage, whilst others present a multiplicity of challenges. These challenges generally afford LO teachers an opportunity to reflect on their initial training and the role that continual professional development is playing. Lessing and De Witt (2007) aver that in the South African context, post the initial professional educator training, teachers' in-service professional development in general becomes sporadic. This poses a challenge to LO teachers, since their curriculum is constantly changing and different from one social context to the next. Therefore, it can never be assumed that Gauteng LO teachers' needs would be similar to the needs of teachers from the other eight South African provinces.

\section{SETTING THE SCENE FOR LIFE ORIENTATION}

Educational transformation, including curriculum reform, has been one of the major agendas internationally that present challenges which sometimes lead to crisis situations in developed, as well as developing countries such; as the USA, China, England, Canada, Brazil, and some African countries. Key to the 'crisis' has been the 'confusion' brought about while bridging the gap between curriculum reform intentions and the realities of implementation at the grassroots level (Zhong 2006, 370). The curriculum reform in South Africa is no exception. Whilst politicians and policy makers were guided by good intentions to bring about transformation to 
the education system that had once been divided along racial boundaries, balancing the political ambitions and the realities at South African schools and in classrooms presented an even greater challenge.

To balance this equation, LO was introduced as a key and compulsory subject in 2002 in the General Phase (Grade R-9) and the Further Education and Training Phase (FET: Grade 1012) being phased in from 2006 in South African schools (DoE 2003a; Orsmond and Gildenhuys 2003). This led to the call to locate the current setting for career development of LO teachers within the profession. It was suddenly expected of them to teach a subject they had never been trained for, exposing a variety of difficulties for them. These difficulties were related to their limited understanding of how to effectively implement the LO curriculum and their limited knowledge of the specific mediating tools and practice skills needed for meaningful LO teaching. This urgently called for addressing their career development needs.

According to the Revised National Curriculum Statement (RNCS) (DoE 2003b, 9), LO is defined as 'the research of the self in relation to others and to society'. By its nature, LO is meant to be a subject that holistically develops learners as individuals who will be able to add value to the democratic society by placing personal and individual needs in a social context that 'enables them to live meaningfully and successfully in a rapidly-changing society’ (DoE 2003b, 9). In addition, because of its multidisciplinary and integrative nature, LO draws on concepts from knowledge domains such as sociology, psychology, political science, human movement science, labour studies, and industrial studies that can be successfully integrated in all other subjects in the school curriculum (Geldenhuys, Kruger and Moss 2013). In turn, this integration seeks to build responsible learners with skills and knowledge that would mitigate the complex and dynamic life challenges they face in the 21st century South African classrooms (DoE 2002). These learners should also be able to make informed decisions and choices with regard to various aspects of life (Ahmed, Flisher, Mathews, Mũkoma and Jansen 2009) and to encourage the acceptance of diversity, thus contributing meaningfully to the productive global economy and promote the quality of life for all as enshrined in the Bill of Rights (Diale 2010; Tshelane 2014). The multidisciplinary nature of the subject, requires input that will provide LO teachers with the knowledge, skills and values that are provided by the various disciplines in which the subject is embedded. They have to develop, define and interpret their roles to suit various contexts they are faced with, ranging from religious/cultural/political/moral/ethical debates and dilemmas to teenage sexuality, teenage pregnancy, HIV / AIDS, poverty and drug and substance abuse (Helleve, Flisher, Onya, Mũkoma and Klepp 2011; Wilmot and Naidoo 2014). However, even though multidisciplinary in approach, many institutions seem not to address this aspect in 
providing LO teachers with support in in-service programmes.

Unlike other content-based subject teachers, LO teachers are expected to act as counsellors for life outside the classroom often in areas beyond their professional education and qualifications (Brown 2013). These expectations expose their vulnerabilities and possible lack of prior training or continual professional development and trigger feelings of helplessness. Therefore, even though LO can be regarded as a key vehicle towards social, political, economic, and educational transformation; its success lies in the successful career development of implementers in the classroom, who are the LO teachers. It is in this context that the article examines the career development needs of LO teachers to establish conditions that are likely to enable them to effectively implement the curriculum and to ultimately achieve the envisaged national priority goals.

\section{CONCEPTUALISING THE CAREER DEVELOPMENT OF LO TEACHERS}

Weinert (2001) defines a career as a blueprint of a person's experiences throughout the life cycle of their working life. Similarly, Savickas (2003) asserts that people's career become a story that they compile about themselves and are shaped during their working life. According to Collin (1998), an individual's career arises from interaction with organisations and society. Furthermore, Savickas (2009) postulates that this interaction is no longer merely just a sequence of jobs but a story that working people are writing about themselves. According to Baer, Flexer, Luft and Simmons (2008), an individual's career development is a lifetime process that encompasses the growth and change process from childhood, the formal career education at school, and the maturing processes that continue throughout a person's adult working life into retirement. On the other hand, Shapiro and Last (2002) define professional development as a process of adult learning that occurs while one is developing the desire to improve and enhance one's knowledge and skills, and examining personally and socially constructed beliefs and ideas about the field of specialization in order to meet the ever-changing challenges of life's needs and roles.

Viewed in this sense, LO teachers' career development is defined as a lifelong process of managing their professional learning and work tasks. Maree $(2015,7)$ further explains that 'these tasks include the acquisition of new attitudes, beliefs and competencies (ABCs)'; all these qualities aim at helping $\mathrm{LO}$ teachers promote their career development.

Although researchers have emphasized the importance of the career and professional development of teachers in different subjects (Diale 2010; Mestry, Bischoff and Hendricks 2009; Mkhwanazi 2013; Wood and Olivier 2007), it has not always been easy to effectively 
identify the career development of LO teachers. These efforts are being curtailed by the challenges caused by the often erratic allocation of LO teaching responsibilities in schools (Singh 2011). Furthermore, the ineffectiveness in policy implementation is greatly complicated by the unresolved tensions LO teachers experience as a result of the constant workload reviews and adjustment of the LO curriculum, leading to the devalued quality of classroom work. This negatively impacts on the teaching of the subject.

\section{THEORETICAL FRAMEWORK: CULTURAL-HISTORICAL ACTIVITY THEORY}

I draw on Vygstsky's (1978) notion of the Cultural Historical Activity Theory (CHAT) to understand the career development needs of LO teachers in the Gauteng Province. The CHAT notion embeds people and artifacts in dynamic activity systems. According to Vygotsky (1978), CHAT is anchored to three core ideas, namely 1) human beings act collectively and learn by doing and communicating in and via their actions; 2) human beings make, employ and adapt tools of all kinds to learn and communicate; and 3) community plays a central role in the process of making and interpreting meaning. This theory emphasizes the psychological, activity-based perspective on human activity and development (Forbes, Madeira, Davis and Slotta 2009). Foot (2014) argues that the theory provides a framework for analyzing professional work practice, thus offering a multi-dimensional systemic approach that includes psychological motives, tools as well as the dynamics of power, money, culture and history (Foot 2014). This author further asserts that in CHAT, human beings are encultured and everything people do is shaped by and draws upon their cultural values and resources. In addition, since cultures are grounded in histories and evolve over time, people's activities must be viewed in light of the historical trajectories of their actions (Foot 2014).

While it is beyond the scope of this article to provide a full description of CHAT, I rely on Engeström's (1987) formulation of the third generation activity theory (AT) to understand the career development of LO teachers in the Gauteng Province. In his triangle diagram (Figure1), Engeström conceptualizes all human activity as the interaction between seven inseparable and mutually constitutive elements which include subjects, objects, tools, outcomes, communities, division of labour, and rules. These elements present a specific transactional aspect of human activity (Yamagata-Lynch and Haudenschild 2006), driven by a goal orientation that mediates interaction between individuals, groups, and collective motives (Anthony 2012). 


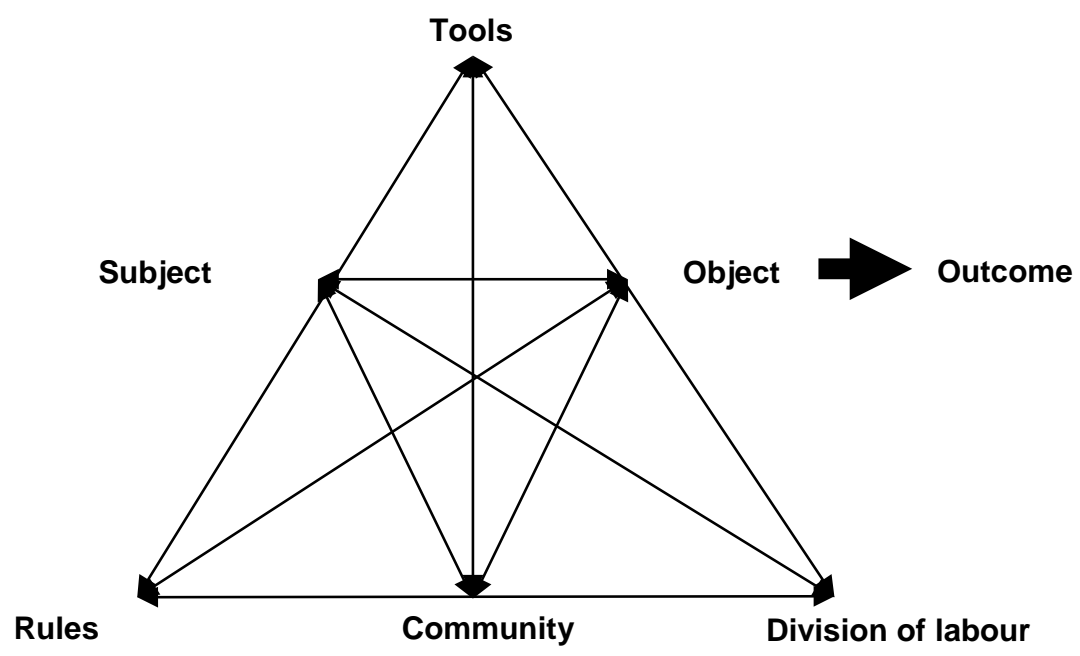

Figure 1: Cultural-historical Activity Theory Model of Human Activity (Engeström 1987)

In the context of this article, the elements of the triangle (Figure 2) represent the various activities involved in the career development of LO teachers. The subject is viewed as an individual or a group of individuals involved in an activity, referred to as LO teachers. The object is the motivating influence behind the subject's participation in the activity, which is the effective implementation of the LO curriculum, learner and teacher knowledge, as well as improved quality of life. Tools such as time, money, curriculum, media, language discourse, colleagues, resources, principal and textbooks act as artefacts mediating activity between the subject and the object. The subject uses physical, cognitive and/or symbolic tools to direct actions towards the object with the goal of producing the outcome, which is to uphold educational, constitutional, transformational, civil, and social responsibilities for all citizens. A community is the social and cultural group that subjects are part of, in this context referring to the school, learners, teachers, parents, administrators, school governing bodies, the community and faith based organizations, and other governmental stakeholders. The division of labour defines how tasks and responsibilities are shared among system participants while they are engaging in joint activities, e.g. roles, status, power issues, new career development responsibilities, and responsibilities defined by the rules and the community. Finally, implicit and explicit rules; including acts, policy, curricular, principals, authorities, regulations, required qualifications, norms, values, and other beliefs; shape the behaviour of the community members (CATDWR 2003). 


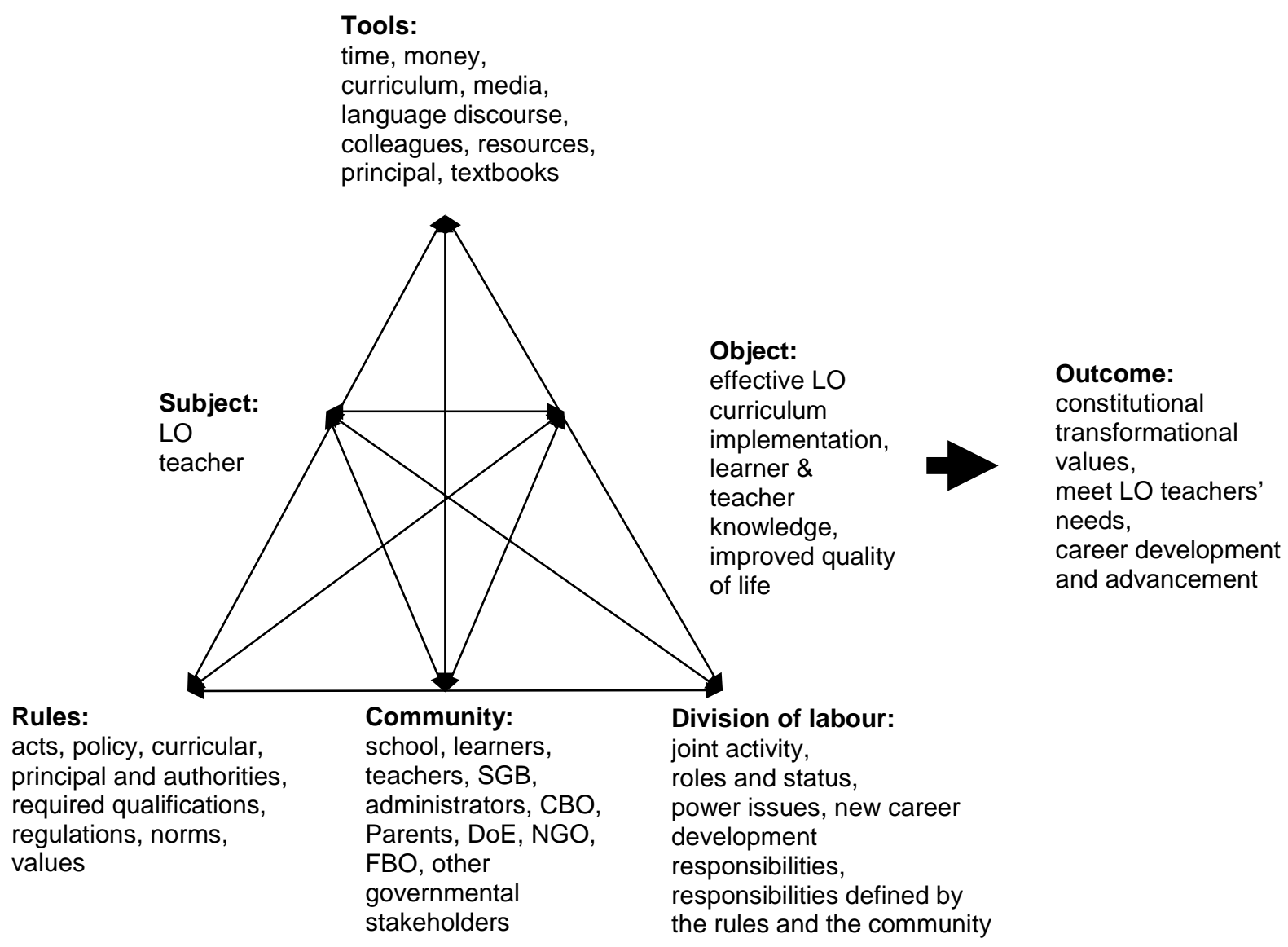

Figure 2: LO teachers' career development needs from an activity system. Adapted from Engeström (1987)

According to Vygotsky (1978), and Cole and Engeström (1993), activity systems do not exist in a vacuum or in isolation but are historically embedded with tensions and contradictions located in each component of the activities. Influenced by the need for continual professional training and development programmes of LO teachers, CHAT can serve as a tool that provides a useful mechanism to enable the multi-faceted analyses of complexities that lead to tensions within and amongst activity systems (Figure 4). These tensions evolve and respond to systemic contradictions within the activity (Foot 2014). Engeström (1987) argues that these systems can either contradict or create an opportunity for expansive learning, since they are heart of learning practice (Engeström 1987).

In keeping with my interest in the tensions observed with regard to LO teachers' career development needs, CHAT affords me the opportunity to explain the personal and professional tensions that LO teachers are experiencing when addressing their career development needs during in-service workshops offered by the GDE. 


\section{RESEARCH AIMS AND OBJECTIVE}

The aim of the study reported here was to explore and identify career development needs of LO teachers in the Gauteng Province. These were needs that were significantly related to their personal and professional experiences. The assumption was that evidence on these aspects would be valuable for planning their continual career development. Congruent to this aim, the following reach question was formulated:

How can LO teachers' personal and professional experiences serve as a useful resource for understanding career needs that can be drawn on in planning their continual professional development in the Gauteng Province?

\section{RESEARCH DESIGN}

The interpretivist paradigm informed the context of this article, since my intention was to gain a deep understanding of how LO teachers' personal and professional experiences could serve as a useful resource for understanding their career development needs in the Gauteng Province. A qualitative research approach was adopted as the data collected was descriptive and focused on participants' responses during individual and focus group interviews. In addition, the findings of the study emerged naturalistically while the research was progressing (Yin 2011). A qualitative research design was regarded as appropriate since it acknowledged that individuals constructed reality in interaction with their social worlds. Creswell $(2013$, 8) contends that 'the qualitative researcher's intent is to make sense of the meanings others have about the world'. In that sense, the article characteristically describes, makes sense of, interprets, or reconstructs the interactions in terms of the needs LO teachers attach to their career development (Merriam 2009).

\section{SAMPLING METHODS AND PARTICIPANTS}

Purposive and criterion-referenced sampling were used to select participants with experience of the phenomenon in order to facilitate learning a great deal about the issues central to the research question (Rule and John 2011). The specific criteria included the ability to speak English or any of a group of African languages (Setswana, Sepedi, Sesotho, isiZulu, and isiXhosa), as well as teaching LO at a school or holding a position at the education district or head office as an LO curriculum specialist. I used data from seven of the nine participants (Table 1) in individual interviews, since no data was generated from the other two participants with regard to the phenomenon. Participants consisted of three African women, three White women and one Indian woman. They all held positon of management with four being heads of departments, two were LO coordinators at the GDE head office, and one was a principal. All 
the participants had more than 10 years of teaching experience while the lowest qualification was a four-year diploma and the highest was a doctorate degree.

Table 1: Profile of participants

\begin{tabular}{|l|l|l|l|l|l|l|}
\hline \multicolumn{7}{|c|}{ Phenomenological individual interviews with LO teachers } \\
\hline Pseudonyms & Gender & Race & Position held & $\begin{array}{l}\text { Teaching } \\
\text { experience }\end{array}$ & $\begin{array}{l}\text { Years of } \\
\text { teaching Lo }\end{array}$ & $\begin{array}{l}\text { Highest } \\
\text { Qualification }\end{array}$ \\
\hline Lilly & F & White & HOD & 26 & 26 & MEd Psych \\
\hline Puleng & F & Black & HOD & 18 & 18 & BEd \\
\hline Liziwe & F & White & HOD & 23 & 23 & 4-year diploma \\
\hline Rebone & F & Black & HOD & 17 & 17 & BEd Honours \\
\hline Martha & F & White & Principal & 24 & 24 & MEd \\
\hline Kate & F & Indian & LO coordinator & Not provided & 3 & DEd \\
\hline Sebonelo & F & Black & LO coordinator & Not provided & 4 & MEd \\
\hline Group member (Codes used) & \multicolumn{5}{l|}{} & \\
\hline FG1P1 & M & Black & Principal & 23 & 2 & BEd \\
\hline FG1P2 & F & Black & HOD & 31 & 2 & BEd \\
\hline FG1P3 & F & Black & Teacher & 15 & 4 & BEd \\
\hline FG2P1 & F & White & Teacher & 3 & 3 & Master's \\
\hline FG2P2 & F & Black & Teacher & 13 & 13 & Honours \\
\hline FG2P3 & F & Coloured & Teacher & 1 & 1 & Honours \\
\hline FG2P4 & M & Black & Teacher & 10 & 2 & Honours \\
\hline FG2P5 & F & Black & Teacher & 12 & 5 & Honours \\
\hline FG2P6 & F & Black & Teacher & 18 & 5 & Honours \\
\hline
\end{tabular}

\section{DATA COLLECTION}

Two data collection methods, namely, individual interviews and focus group interviews, were used to explore how LO teachers' personal and professional experiences could serve as a useful resource for understanding their career development needs in the Gauteng Province. A structured individual interview schedule with open ended questions was used to elicit data. Although a variety of interview questions were posed in the comprehensive study, I drew on only two for this article: 1) What are your personal and professional career needs that will enable you to effectively teach LO? 2) How can your personal and professional experiences serve as a useful resource for understanding and planning your continual professional development?

The participants were probed to explore issues that affected their career needs and eventually led to their ineffective implementation of the LO subject. Whilst the interviews focused on the career development needs of the participants, I was more flexible by allowing their ideas to guide the process (Gillham 2005). Therefore, participants were allowed the scope to speak more widely about the issues raised during the interviews, since I envisaged that their career development needs would have had an impact on other aspects of their personal and 
professional lives.

The second data collection method used to triangulate information received during the individual interviews was focus group interviews. The focus group interviews were valuable, since participants were able to listen to one another's responses, which enabled an in-depth conversation because they offered additional responses beyond their own initial responses (Merriam 2009). Focus group interviews were conducted with two sets of LO teachers. One of the focus groups in this study comprised a group of three teachers from one school in the Sedibeng District. The interview was held at their school and the principal was one of the participants, since he was an LO teacher. Two members of staff teaching LO were absent from school when I conducted the focus group interviews. The second group of participants came from different schools and were all classroom teachers. The interview was held in a venue conveniently arranged at the university. All focus group participants were given codes for identification.

This triangulation approach of also conducting focus group interviews added a valuable perspective to the research findings, since all seven participants in the individual interviews were in leadership positions. The focus group interviews captured the 'collective voice' of the classroom teachers. Their participation could possibly be used as an opportunity to rally for change in addressing the career development needs of LO teachers.

\section{DATA ANALYSIS}

Babbie and Mouton (2007) view analysis as the examination of the parts that comprise a complex phenomenon. Content analysis was employed using Tesch's method of data analysis that included open, descriptive coding techniques (Creswell 2007). The individual and focus groups interviews were transcribed verbatim by an independent transcriber. I personally verified the transcripts by reading them while listening to the voice recording. During the analysis and interpretation stage, I considered the two sets of data collected from the individual interviews and focus group interviews in relation to each other and to the research question with the aim of arriving at common categories and themes in order to understand the career development needs of LO teachers in the Gauteng Province. Furthermore, the conceptual and theoretical literature reviews were contextualized to verify the findings of the analysis and to support the interpretations of the research findings.

\section{ETHICS}

The University Higher Degrees and Ethics committees granted approval for the research 
(Reference number 160/27/07/07). Further permission was granted by the Gauteng Department of Education to conduct the study at schools. Informed consent was obtained from the participants. To safeguard the dignity, rights, safety, and well-being of the participants during this research project, participation was voluntary and participants were completely aware of their right to withdraw from this study at any time without explanation or prejudice. Their privacy and anonymity were also guaranteed. I used pseudonyms for all individual participants. Although the research project yielded valuable results that could be considered in other provinces, the results of this research could not be extended, since the nature of the research design was contextual.

\section{DATA ANALYSIS}

Babbie and Mouton (2007) view analysis as the resolution of a complex whole into its parts. Content analysis was employed using Tesch's method of data analysis, which implies open, descriptive coding techniques (Creswell 2007). The interviews conducted with individuals and the focus groups were transcribed verbatim, with the help of an independent transcriber. I personally verified the transcripts by going through them again. During the analysis and interpretation stage, I considered the two sets of data collected from the individual interviews and focus group interviews in relation to each other and to the research question to arrive at common categories and themes so as to understand the career development needs of LO teachers in Gauteng. Furthermore, the conceptual and theoretical literature undertaken was contextualised to verify the findings of the analysis and support the interpretations in the research.

\section{FINDINGS}

In responding to the career development needs of LO teachers and the enablers to effectively implement the Life Orientation curriculum, five major themes emerged from the analyses. These major themes are discussed and supported by selected excerpts from participants' contributions that informed a particular theme.

\section{Theme 1: The need for in-service training}

The data indicated LO teachers' need for in-service training in the field of LO as an important aspect of their career development. They alluded to the fact that although several workshop opportunities had been facilitated by the GDE in the past, those interventions yielded no positive results, since most of the appointed service providers and facilitators were themselves 
not conversant with the content of this new subject. That left LO teachers frustrated and feeling inadequate to teach socially sensitive topics; such as sexuality, HIV and AIDS, and religion in their classrooms. In responding to her training as an LO educator to effectively implement the curriculum, Liziwe, who was an HOD at one of the former model C high schools, stated that there was not enough professional development offered to them to advance their career as Life Orientation teachers:

I didn't have any formal training. When I became head of department of educational guidance, I went for I think it was a four-day course by the TED [Transvaal Education Department] in those days [referring to pre 1994] where they said you know you got to do some education on sexuality education and this is how you handle it. Here is [sic] some few notes for you but I think just the experience of working with it, it's the way to go. I taught myself, I still teach myself and do trial and error even now.

Martha, who was a principal at a former model C primary school also alluded to such a lack of in-service training:

In most cases, especially if these [referring to sensitive issues listed earlier] have to do with the home background, ailments, delinquency, etc. Other teachers take it to be the LO teacher's work and refer them to you; that is why I refer to the need of [sic] training in counselling.

When asked if she had received any training to deal with these 'home background' issues, Martha’s response was:

Actually not much. As I said earlier, most of my learning in LO was incidental learning or selflearnt.

An important issue raised in relation to the inadequate training offered was linked to the lack of knowledge of the facilitators who were training them. In voicing her concern about the poor training of LO teachers, and to corroborate Martha’s claims, FG1P3 said:

Now it's there, but it's not enough. I think people who are also training us, they still need training. They are not well equipped. You see, with this changing of the curriculum [referring to changes from NCS to RNCS] it is not easy; it's not easy at all.

In contrast to the reports by these teachers at the school level, the departmental officials at the head office reported that continual development was taking place. In her response to the questions about the professional and career development offered to LO teachers, Sebonelo stated:

I do a lot of training. I organise workshops with them and sometimes in collaboration with other departments. So, we are doing training every time; from time to time, we do training on unpacking 
the curriculum. So, everybody is on the same level; so, they understand what is going on.

In support of her colleague, another official, Kate, responded to the question about the adequate training of LO teachers:

We have given training, right, and I can only put it to you this way. When you have a transformation in a country ... and you've got a new curriculum launched ... and you want change in a country and we've all known that transformation had to come up and you're trying to bring in a new dispensation and a new understanding. You can either go very slowly with the process or you can do what our government has done. What we've chosen to do is to bring about change and bring radical change, because otherwise it would have taken very long to see educational transformation.

This contrast was a cause for concern as it indicated that there was no articulation or common ground between teachers who were policy implementers and the department of education who were policy makers. That was also worrisome on another level. Although the officials referred to doing a lot of training with teachers, in reality it is a known fact that their involvement meant organising and coordinating such training to be conducted by service providers, who were mostly inadequately trained or informed about the curriculum and lacked hands-on experience of classroom realities that LO teachers had to deal with. In addition, the impact of the radical change referred to by the second official was never reviewed in either the classroom or the school context, thus causing contradictions and tensions between the schools and the department.

\section{Theme 2: The need for subject and content knowledge development}

Amongst the various topics mentioned as being needed for their professional development, the two issues that continually kept surfacing were the need to gain knowledge and to understand the content of cultural diversity and sexuality issues when addressing the need for skills, knowledge, and content. Related to this, Martha’s commented:

Teachers are used to pen and paper kind of development as they find it challenging to teach content of [the] LO curriculum. There is also [a] need for skills and knowledge development in issues around counselling, levels of child development, sexuality issues, bullying, violence, learning outcome 4: physical education.

In reference to the need for content knowledge, Lilly stated:

I think that some teachers find the sexuality thing difficult, the careers because of lack of knowledge ... I think that, um, some teachers would be multi religion, um, find that a bit difficult, because they have their own religious dogma, you know, and that does tend to sneak in sometimes .... Ja [sic], and you know, things like if you're teaching about sexuality; you've got to teach about abortion and that raises a whole lot of moral issues for people. 
Undoubtedly, the inadequate subject and content knowledge of different people who were responsible for interpreting policy for teachers left them frustrated as they were not sure who to listen to and ultimately what to do in class. The aforementioned issues relate to the daily realities of the LO teachers' own personal and career lives, a fact which makes the call for further career and professional development of LO teachers even more compelling.

\section{Theme 3: The need for support from significant others}

People are usually surrounded by those who care and love them. These individuals are present in the various circles where they interact with other human beings; be it at home, in society, or at their workplaces. During challenging times in their personal lives, people find themselves reverting back to these relations for comfort and solace. It is in the absence of such relations in people's lives that they find themselves drowning in negative emotions; such as stress, depression, unhappiness, and poor self-efficacy as career beings (Sum, Saboor and Sahaf 2015, Zembylas 2003). Based on this, an important attribute of the career development of LO teachers is the need for support by key stakeholders. Most LO teachers found solace in both their internal and external support structures. Whilst all participants reported positively on the role played by their school-based support teams and the Gauteng Department of Education, it was obvious from their general accounts that they appreciated the support received from external stakeholders and were keen to build stronger relationships with those relevant external bodies. The collaboration with other stakeholders was lucidly captured by Lilly:

Um, we work with all our local churches, I ... I ... have networked with all of them and a lot of the churches offer social services. So, I will often ask them to intervene, with the child's permission, um, and if the child belongs to that congregation.

Whilst her initial comment on religious groups used as support systems was general without alluding to a particular religion or congregation, Lilly specifically commented on community and non-governmental organisations that offered them support with regard to social challenges they were encountering with learners at schools. That assumption was reflected in her statement:

Um, we worked with FAMSA, and SANCA; both of them used to come in and do training in the classrooms .... We use the local police, we have good working relationships both with the CPF and the police actually help us a lot .... We use NICRO, um, we've sent children on diversion programmes to NICRO if they're involved in ... in criminal activities as part of our school punishment if you like.

Liziwe further corroborated Lilly’s comment on the important role of outside stakeholders: 
T.M.I [Transvaal Memorial Institute for Child Health \& Development] helps us a lot; they are, I can say, professional people who I can send a child to the psychologist and say, please. I don't know what to do anymore... then social workers also help a lot with the experience that they've got.

Participants reported that for Life Orientation curriculum to be meaningfully facilitated, there is a need for taking ownership by all these stakeholders. Although different stakeholders were mentioned, the important role played by the school principal and the school management team was repeatedly emphasised. Lilly's comment on the role of the principal and the school management team was:

Well, I think ... You know, the most important source of support is your management team, your principal, and your governing body. You've got to have them valuing the subject and recognising its worth in the curriculum.

In explaining the support by the school management team (SMT) and district officials or lack thereof, participants held contrasting views. While some of the participants reported an overwhelming support by the leadership and management, some expressed a lack of such support from the structures that were meant to offer the support. On a positive note, Liziwe and Puleng unambiguously claimed to be receiving support from their principals in their responses. Liziwe stated:

My principal is very open-minded and he is always looking for new things and new ideas and that helps a lot.

Puleng supported her by saying:

I think ... I think I've got a very supportive, eh, head principal and I've made a point that even if when you've got meetings, when they say life orientation at the back, then I said no always, no ways, I'm not going there quiet [sic], I'm forward; everything LO then the rest will follow.

Interestingly, the support offered by the GDE seemed to depend on the district where a participant was based. Participants reported both positive and negative support by district officials. Lilly negatively experienced the support from her district as reported:

I think that the ... the educational support services within the Department are very poor. I think they're very ... they're overwhelmed.

In contrast, FG2P4 from another district related the following positive story:

In my district, I think that the structure for support is categorically clear. It all depends on teachers or Life Orientation teachers how they view that. We have our Life Orientation there at schools to 
identify and deal with the problems and if learners need to be referred, the district is available. They've got learner support, they've got ISS, they've got DBST. So, the system is there to support the processes.

In general, the research results gave hope as participants reported a positive buy-in from other stakeholders, which they had developed into networks of support to help them deal with their challenges. FG2P5 claimed that:

We are coping because we are liaising with different stakeholders. We can communicate with other community members, parents, and business people.

Finally, it was interesting to observe how third party opinions from told stories influenced the ways in which other people not affected by the lack of support viewed this phenomenon. Although not directly affected by the situation, FG2P1 stated the lack of support for LO teachers based on what she had heard from other people in the field:

I do not know if earlier we spoke about support; the Department has a lot of structures in place and I don't have a lot of experience because I am in a private school but a lot of the teachers are saying that support is inadequate or there's not enough of it. I know that that's an area that's being developed but Life Orientation teachers need more support.

A community of practice is described by Lave and Wenger $(1991,98)$ as 'a set of relationships between persons, activity and their world, over time and in relation to other tangential and overlapping communities of practice'. Teachers, in essence, can be viewed as practitioners who belong to a community of practice because they share a joint enterprise, function as a community, and develop a common repertoire. Cook $(1997,3)$ argues that 'community support is essential for creating the professional development opportunities teachers require to help their students reach higher levels of learning'.

\section{Theme 4: The need for resources}

The fourth important need raised by participants was the need for resources. Although the subject had been introduced a few years ago, there were still visible challenges to its implementation at most schools. As a result, teachers were still finding their feet in translating the policy statements into practice. Generally, perpetual LO educator migration, lack of textbooks, timetabling, human resources, physical space, and resources to fulfil portfolio tasks such as first aid training and learner/ driver licence were seen as major obstacles at their schools and in subject content. Puleng expressed her perception about these resource challenges:

Lack of resources and then sometimes you find that you were to deal with certain issues in a 
confidential manner. There's no, like I said, resources; there's ... there are no resources ... um, counselling room and sometimes like you can see that I've got a little bit of resources but I cannot just leave them in the class because of security.

In addition, timetabling as a resource that supported effective school functioning presented another challenge. Lilly said:

And we also fight, we have to fight for the time allocation on the timetable. So, we are pretty close now to what the GDE have recommended. You will find in a lot of schools; the Life Orientation programme is not given sufficient time.

Sebonelo supported Lilly's statement. As a provincial coordinator, Sebonelo voiced three major challenges facing Life Orientation; namely time allocation in the school timetable, continual migration of LO teachers, and LO used as an 'add-on' to fill up teachers' individual timetables at schools. Sebonelo captured her frustrations:

Well first, it is not allocated the way it is supposed to be allocated in some of the schools and when you visit the schools, you find that during the Life Orientation periods they are doing other learning areas, like catching up on maths or natural sciences and one wonders when they are going to then do all the LOs.

Alluding to internal struggles at schools, Puleng said:

You find that you go back to the schools; when you come back, you are overwhelmed, you want to implement but because of the resources and the red tape, you know, it's difficult ... it's difficult and sometimes it can be overwhelming and discouraging.

Van Deventer $(2009,40)$ argues that 'it is educationally unsound to implement a new subject without having the necessary human resources to present it'. Furthermore, Rooth (2005) asserts that the lack of success in LO implementation could be attributed to different factors such as the lack of resources, access to needed information, inefficient teacher professional development, and learners', educators' and school principals’ perceptions of this learning area and its constituents.

\section{Theme 5: The need for stability in the LO subject}

One of the main challenges that undermined the successful implementation of LO at many schools was the lack of stability of the subject, both from the internal schooling context to the external curriculum and policy developers. During the interviews, it was obvious that most of the participants perceived their principals and colleagues as not respecting them and their subject. They commented on how they were used as ancillary resources that prevented them from finding stability in teaching LO. One of the officials, Sebonelo, expressed her frustration 
about the constant migration of LO teachers at schools by saying:

One challenge would be that you'd train one Life Orientation teacher this year, then they'd move that teacher to teach another learning area. If there's a space in maths, they'd move that teacher to maths.

However, from the school-based participants' perspective, that lack of stability was caused by the inability of the GDE to take a stance on the requisites for effective LO teaching. Rebone, one of the HODs for LO succinctly noted the challenges of stability was caused by the GDE:

GDE is not sure of outcomes and what they want. There is no standardisation and this is a joke, a big grey area. So, you learn to keep quiet and accept a lot of things.

Timetabling was also referred to as a challenge that caused instability in the subject. LO teachers' experiences were that schools allocated all the other priority subjects first before allocating the LO resources. Such an approach led to the constant migration of LO teachers to other subjects while no one really is afforded an opportunity to specialise in LO and to become a knowledge expert in the subject. Alluding to the timetable challenges, Sebonelo declared:

What normally happens, if I'm teaching Life Sciences, for [sic] whole year 3rd period. So, they will add on with Life Orientation to make up for it. So, it is now regarded as an add-on learning area. Not as a stand-alone learning area. Normally, what I say to schools or to districts is that it is the policy and it has to be regarded as one of the important learning areas.

She was supported by FG1P1 who brought up the issue of the changing curriculum:

Ma'am is right; it was RNCS now its NCS... keep on chopping and changing when we are getting use to this all the current [sic] is changed, so they are confusing us. I think now that the $\mathrm{R}$ has been removed, now it's National Curriculum Statement; they must get us professional people to come and train us how to do this NCS plus it's consistence; we must understand it in the same way. Because we use to have this problem, the facilitator will tell you this time when the other one comes tell you a different story.

The need for stability in the subject area was mentioned as an important factor in the future success of LO teaching. This information confirmed studies conducted on LO teachers regarding the noticeable lack of stability and permanence in LO positions within the schools, and the fact that many teachers were not qualified to teach LO, thus impacting on their career development and subject specialisation and knowledge - sentence long (Christiaans 2006; Rooth 2005; Van Deventer 2008). To address this need, I concur with Corcoran (1995) that LO teachers should be provided with sufficient time, stability and follow-up support to master the new content and strategies and to integrate them into their classroom practice. 


\section{DISCUSSION}

Based on the aforementioned themes, LO teachers' career development needs can be explained at five different levels, beginning from the most intrinsic needs to the most extrinsic needs (Figure 3). At an intrinsic level, personal and career development needs, such as the need for formal training and the need for subject and content knowledge development can be achieved by exploring the Continuing Professional Teacher Development (CPTD) programmes offered by SACE accredited service providers and higher education institutions (Departments of Basic Education and Higher Education and Training 2011). However, the core of their effectiveness during curriculum implementation in the classroom rests on those career development needs that are extrinsic in nature over which LO teachers have no control. Challenges; such as the need for support from key stakeholders, the need for resources, and the need for stability in the LO subject are beyond their circle of control and fully depend on the other important role players; such as the school management teams, community-based organisations, and the GDE. This process requires a focus on the core importance of interrogating the career development of LO teachers from the perspective of a systemic model.

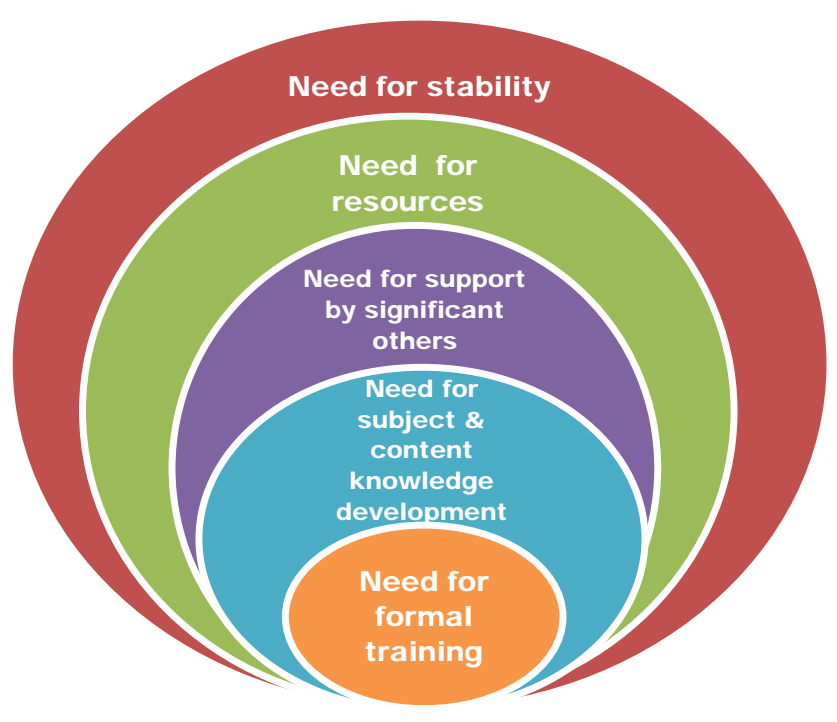

Figure 3: LO teachers' career development needs: From an intrinsic level to an extrinsic level

The findings clearly illustrated that most of the LO teachers who participated in the study were frustrated with their unmet LO career development needs. Failure to satisfy those needs made it impossible for them to carry out their mandate of ensuring effective LO curriculum implementation. Van Deventer $(2009,140)$ argues that 'it is educationally unsound to implement a new subject without having the necessary human resources to present it'. Taking a deeper look at the findings presented in this research, they clearly reflected the tensions and contradictions observed throughout the research process (Figure 4). It is in the context of these tensions that AT (Engeström 2001) was appositely utilised to understand the career 
development needs of LO teachers.

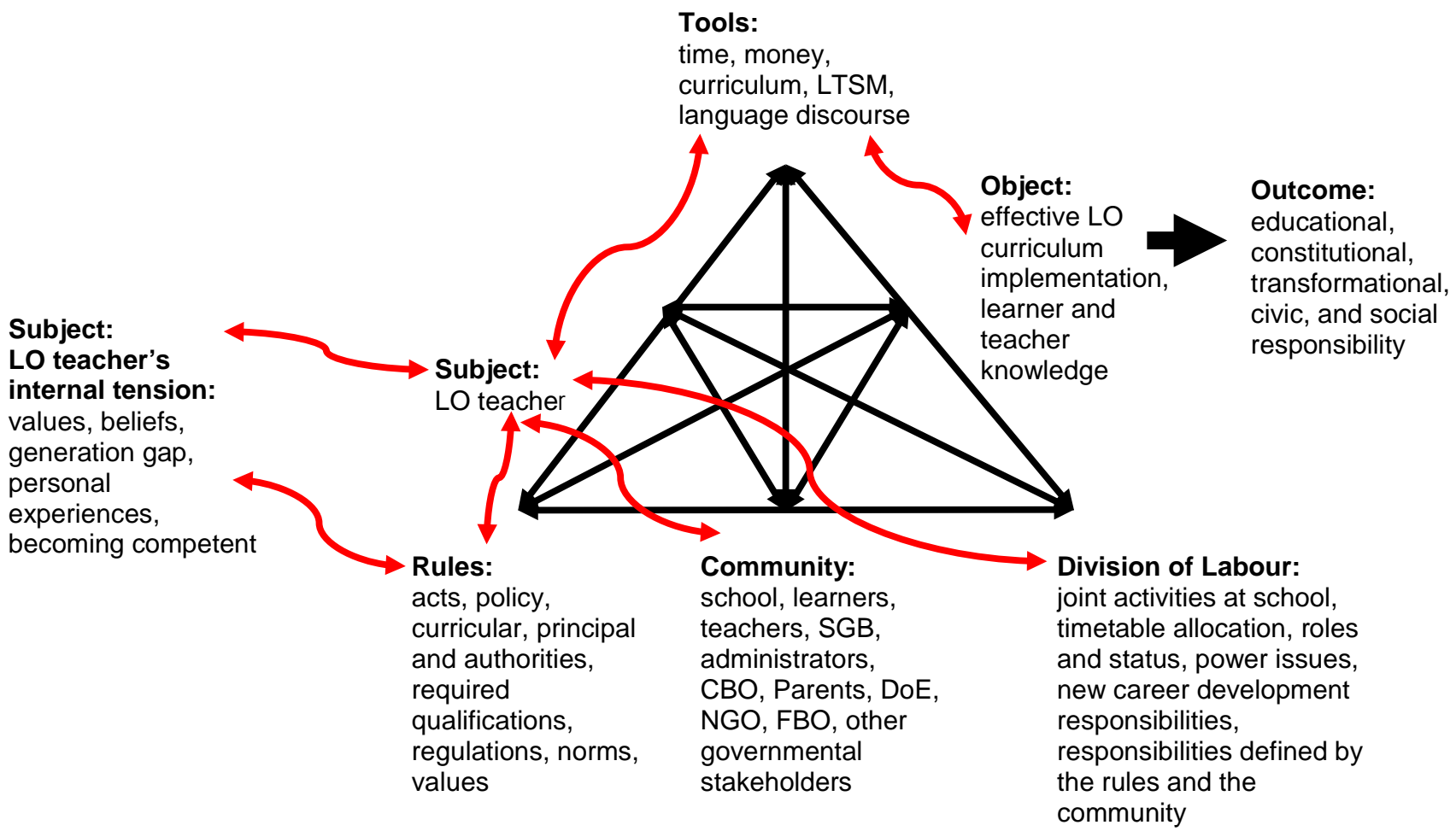

Figure 4: Tensions amongst various activity systems of LO teachers' career development needs (represented by arrows)

The foremost tension was the intrinsic need of LO teachers for formal training with the view of enabling them to effectively implement the LO curriculum. This need created tension between the rules set (e.g. the policies, curricula, the authorities) that were institutional imperatives and the subject teaching that was the individual prerogative of the LO teachers. Furthermore, the LO teachers' need for subject knowledge was evidenced by the tension observed between the tools available to them (e.g. time, money, the curriculum, and learning support material) and the object (effective implementation of the LO curriculum, as well as learner and educator knowledge). The available training as reported by one of the GDE officials was perceived as superficial and generic, since it did not address the content of the subject adequately. Based on those poor training events, LO teachers indicated that they were not fully qualified to teach the subject (DoE 2009; Van Deventer 2008).

In addressing LO teachers' need for formal training, Corcoran (1995) and MacNeil (2004) concede that educator professional development programmes in their present state often have little or no practical value to teachers and follow-up on teachers' experiences is seldom done. These initiatives neglect the past knowledge, skills, values, practices, and beliefs that teachers bring to their current reality while impacting on their career and professional activity (Opfer 
and Pedder 2011). These circumstances exacerbate tensions between the LO teachers as subjects in the activity and other elements of the activity system such as the object, the rules, the community, the division of labour, and the tools), resulting in further confusion and uncertainty among LO teachers (DoE 2009; Christiaans 2006; Rooth 2005).

The report by the task team for the implementation of the NCS further emphasises the training needs, since it has become necessary to re-assert teachers' roles as subject experts with the purpose of supporting their work in the classroom (DoE 2009). Placing teachers in situations where they lack expertise or find themselves out of their depth not only creates stressful situations for the teachers, but raises a number of questions about the learners (Van Deventer 2009). They adeptly sense the 'incompetence' of the teachers and question the value of LO when it is either presented by 'unqualified' teachers or shifted from one educator to the next from year to year (Van Deventer and Van Niekerk 2008, 135).

Considering the extrinsic nature of LO educator's needs, participants were frustrated by the lack of support from the school system and the district office. Although LO is said to be a core and compulsory subject at all levels, there was a sense of a lack of support from internal stakeholders. Whilst various authors emphasise the facilitative role that can be played by principals as key supporters of their staff and learners (Hayes and Puriefoy 2004), the lack of support by principals in terms of the status of $\mathrm{LO}$ at their schools is also noted in other studies (Christiaans 2006; Rooth 2005; Tlhabane 2004). Most principals fail to recognise that they are the central agents in sustaining innovations (Fullan 2002). It is they who carry the message about the importance of curriculum innovation (Hall and Hord 1987; Hopkins, Ainscow and West 1994). Their lack of supporting curriculum innovation is evident in the tension observed between the subject (LO teachers) and the division of labour (e.g. joint activities at school, timetabling, roles and status, as well as power issues) at schools. LO teachers indicated that some of their colleagues are not supportive and fail to treat them with the respect they deserve. LO is not considered as an important subject like other subjects at schools.

By nature, LO is a broad content-based subject; therefore, the lack for resources is more pronounced, since it causes curriculum deficiencies, especially when addressing issues; such as coping with HIV and AIDS, coping with grief, coping with retirement, financial planning, and research methods (Theron and Dalzell 2006). Du Toit, Van der Merwe and Rossouw (2007), Prinsloo (2007), and Van Deventer and Van Niekerk (2009) have explored the challenge of poor resources at many schools as an inevitable legacy of apartheid. This milieu creates tensions between the tools (e.g. money, textbooks, and the curriculum) and the rules (e.g. Acts, policies, and qualifications) because state resources remain inadequate to elevate the standards that white 
South Africans were enjoying prior to 1994 (Mathieson 2001).

The disposition at many schools that LO can be taught by any educator remains a conviction that results in the continual migration of teachers in the subject and the instability amongst LO teachers. As revealed in the findings of this research, I argue that unless teachers' needs and tensions in the LO activity system are addressed, it will be impossible for LO to achieve its constitutional and educational transformational goals as described previously. I concur with Christiaans (2006), Prinsloo (2007), Hendricks (2004), and Welton (2001) who suggest that an action-orientated approach should be adopted in relation to specialisation in teaching LO.

\section{RECOMMENDATIONS AND CONCLUSION}

LO teachers' career development is a vital concept in South Africa's era of educational transformation. Findings in this article offer new insights into the relationships between challenges faced by LO as a subject and LO teachers' views on their career and professional development. The results showed that LO teachers' had a high need for career development. In addition, the article revealed that LO teachers' needs were at different levels ranging from intrinsic to extrinsic needs. The results urge that school management and policy makers should take necessary actions to support and fulfil the career development needs of LO teachers in order for them to cope with the demands of changing schools and provide effective strategies to create improving schools.

It is imperative that in planning LO teachers' career development, the GDE should take into consideration their perceived attitudes, ages, gender, religion, culture, belief and life experiences. It is recommended that the programmes be structured to address these contextual needs and challenges, as against the generic programmes currently offered by the GDE and the service providers (both internal and external). There is further need for a closer collaboration between the schools, the GDE and universities in terms of research, the empowerment and support of LO teachers. In the same vein, a large-scale cross-provincial study that compares the status and career and professional development opportunities offered by different provinces to LO teachers should be pursued.

If $\mathrm{LO}$ is to reclaim its rightful place in the secondary and higher education systems, LO teachers' career development needs should be viewed as work in progress to bring about social, economic, political and educational changes. Their roles are bound to be diverse and complex; yet individually enriching and rewarding. Therefore, it should not be delimited by a general curriculum. Whilst the curriculum has its role as a guiding policy for classroom teaching, there 
is a need to be more conscious of the reality that LO reaches far beyond the normal classroom curriculum based on textbooks. Human lives extend far beyond paper and policy. It is important to acknowledge that LO teachers' life stories provide meaning and continuity to their career development. This means that $\mathrm{LO}$ teachers are relying on their own inner resources to construct their career stories. In constructing these stories (Savickas 2011), the tensions created by the need for career development can lead to LO teachers’ expansive learning opportunities and mark the start of a system's reflection process since their educational role goes beyond the call of duty (Engeström 2001).

The results of this article need to be interpreted with caution in that it reports on a small scale sample. A large scale research is needed to document, over time, the career development that LO teachers undergo in all provinces of South Africa and to determine this impacts on teaching the subject. Such research will then inform policy makers, training institutions and service providers on how to structure both the training and development opportunities for LO teachers.

\section{REFERENCES}

Ahmed, N., A. Flisher, C. Mathews, W. Mũkoma and S. Jansen. 2009. 'HIV education in South African Schools: The dilemma and conflicts of teachers.' Scandinavian Journal of Public Health 37(2): 48-54.

Anthony, A. B. 2012. Activity theory as a framework for investigating district-classroom system interactions and their influence on technology integration. Journal of Research on Technology in Education 44(4): 335-356.

Babbie, E. and J. Mouton. 2007. The practice of social research. Belmont, California: Thompson / Wadsworth.

Baer, R. B., R. W. Flexer, P. Luft and T. J. Simmons. 2008. Transition planning for secondary students with disabilities. New Jersey: Pearson Education Inc.

Brown, J. 2013. Attitudes and experiences of teachers and students towards Life Orientation: A case study of a state-funded school in Eldorado Park, South Johannesburg. A research report submitted to the Faculty of Humanities, University of the Witwatersrand, in partial fulfilment of the requirements for the degree of Masters of Arts in Development Studies.

CATDWR see Center for Activity Theory and Developmental Work Research.

Center for Activity Theory and Developmental Work Research. 2003. The activity system. http://www.edu.helsinki.fi/activity/pages/chatanddwr/activitysystem (accessed 18 February 2016).

Christiaans, D. J. 2006. Empowering teachers to implement the Life Orientation learning area in the Senior Phase of the General Education and Training Band. Unpublished master's thesis. Stellenbosch: Stellenbosch University.

Cole, M. and Y. Engeström. 1993. A cultural historical approach to distributed cognition. In Distributed cognitions: Psychological and educational considerations, ed. G. Salomon. NY: Cambridge University Press.

Collin, A. 1998. New challenges in the study of career. Personnel Review 27(5): 412-425.

Cook, C. J. 1997. Critical issue: Finding time for professional development. http://www.ncrel.org/ 
sdrs/areas/issues/educatrs/profdevl/pd300htm (accessed 22 October 2015).

Corcoran, T. B. 1995. Helping teachers teach well: Transforming professional development. Philadelphia: CPRE Publications.

Creswell, J. W. 2007. Qualitative inquiry and research design: Choosing among five approaches. London: Sage Publications.

Creswell, J. W. 2013. Qualitative inquiry and research design: Choosing among five approaches. 3rd edition. California: Sage Publications.

Diale, B. M. 2010. Educational-psychological practice framework for the personal and professional development of Life Orientation teachers in the Gauteng province: A mixed method study. University of Johannesburg, Johannesburg - PhD Thesis

Diale, B. M., J. Pillay and E. Fritz 2014. An exploration of the dynamics in the personal and professional development of Life-Orientation teachers in the Gauteng province in South Africa. Journal of Social Sciences 38(1): 83-93.

DOI see Department of Education see DOI. 2002. Revised National Curriculum Statement Grades R-9 (Schools). Life Orientation. Pretoria: Government Printers.

Department of Education. 2003a. Curriculum 2005. Pretoria: Government Printers.

Department of Education. 2003b. National curriculum statement: Grades $R$ - 9. Pretoria: Government Printers.

Department of Education. 2009. Report of the task team for the review of the implementation of the National Curriculum Statement. Pretoria: Government Printers.

DOI see Department of Education.

Du Toit, D., N. van der Merwe and J. P. Rossouw. 2007. Return of physical education to the curriculum: Problems and challenges facing schools in South African communities. African Journal for Physical, Health Education, Recreation and Dance 13(3): 241-253.

Engeström, Y. 1987. Learning by expanding: An activity-theoretical approach to development research. Helsinki: Orienta-Konsultit.

Engeström, Y. 2001. Expansive learning at work: Toward an activity theoretical reconceptualization. Journal of Education and Work 14(1): 133-156.

Foot, K. 2014. Cultural-historical Activity Theory: Exploring a theory to inform practice and research. Journal of Human Behavior in the Social Environment 24(3): 329-347.

Forbes, C. T., C. A. Madeira, E. A. Davis and J. D. Slotta. 2009. Activity-theoretical research on science teachers' learning: Challenges and opportunities. Paper presented at the annual meeting of the American Educational Research Association, April. San Diego.

Fullan, M. 2002. The change Leader. Educational Leadership May: 16-21.

Geldenhuys, J. L., C. Kruger and J. Moss. 2013. Selected South African Grade 10 learners' perceptions of two learning areas: Mathematical Literacy and Life Orientation. Africa Education Review 10(2): 298-322.

Gillham, B. 2005. Research interviewing: The range of techniques. London: Open University Press.

Hall, G. E. and S. Hord. 1987. Change in schools: Facilitating the process. Albany, NY: State University of New York Press.

Hayes, C. and W. D. Puriefoy. 2004. Teacher professional development: A primer for parents and community members. Washington, DC: Public Education Network (PEN).

Helleve, A., A. Flisher, H. Onya, W. Mũkoma and K-I. Klepp. 2011 'Can any teacher teach sexuality and HIV/AIDS? Perspectives of South African Life Orientation Teachers. Sex Education 11(1): 13-26.

Hendricks, P. C. 2004. The role of physical education in South African primary schools. Unpublished master's thesis. Cape Town: University of Western Cape. 
Hopkins, D., M. Ainscow and M. West. 1994. School improvement in an era of change. London: Cassell.

Lave, J. and E. Wenger. 1991. Situated learning legitimate peripheral participation. Cambridge: Cambridge University Press.

Lessing, A. and M. de Witt. 2007. The value of continuous professional development: Teachers' perceptions. South African Journal of Education 27(1): 53-56.

MacNeil, J. D. 2004. School and cluster-based teacher professional development: Bridging teacher learning to the schools. Working Paper \#1 under WQUIP1's Study of School-based Teacher Inservice Programs and Clustering of Schools. USA, World Education, Inc.

Mahlomaholo S. M. G. 2012. Early school leavers and sustainable learning environments in rural contexts. Perspectives in Education 30(1): 101-110.

Maree, J. G. 2015. Blending retrospect and prospect in order to convert challenges into opportunities in career counselling. In Exploring new horizons in career counselling. Turning challenge into opportunities, ed. K. Maree and A. Di Fabio. Rotterdam: Sense Publishers. Rotterdam: Sense Publishers.

Mathieson, S. 2001. The role of the ANC Education Study Group in the legislative and policy process. In Implementing education policy. The South African experience, ed. Y. Sayed and J. Jansen. Cape Town: UCT Press.

Merriam, S. B. 2009. Qualitative research: A guide to design and implementation. San Francisco: JoseyBass Inc.

Mestry, R., T. Bischoff and I. Hendricks. 2009. Perceptions of teachers on the benefits of teacher development programmes in one province of South Africa. South African Journal of Education 29(4): 475-490.

Mkhwanazi, S. 2013. Teacher professional learning: An analysis of teachers' views on their professional content knowledge. Journal of Social Sciences 37(2): 179-187.

Opfer, D. and D. Pedder. 2011. Conceptualizing teacher professional learning. Review of Educational Research 81(3): 376-407.

Orsmond, C. and C. Gildenhuys. 2003. 'Life Orientation - It's now or never'. Paper presented at Kenton Conference, Johannesburg. November.

Prinsloo, E. 2007. Implementation of Life Orientation programmes in the new curriculum in South African schools: Perceptions and principals of Life Orientation teachers. South African Journal of Education 27(1): 155-170.

Rooth, E. 2005. An investigation of the status and practice of Life Orientation in South African schools in two provinces. Unpublished doctoral thesis. Western Cape: University of the Western Cape.

Rule, P. and V. John. 2011. Your guide to case study research. Pretoria: Van Schaik.

Savickas, M. L. 2003. Advancing the career counselling profession: Objectives and strategies for the next decade. The Career Development Quarterly 52(1): 87-96.

Savickas, M. 2009. Narrative career counselling: Life story approach. Informal talk attended on 24th April. University of Johannesburg.

Savickas, M. L. 2011. Reshaping the story of career counselling. In Shaping the story: A guide to facilitating narrative career counselling, ed. K. Maree. Sense Publishers. Rotterdam: Sense Publishers.

Shapiro, B. and S. Last 2002. Starting point for transformation resources to craft a philosophy to guide professional development in elementary science. In Professional development of science teachers: Local insights with lessons for the global community, ed. P. Frasser-Arbder. New York: Routledge Falmer.

Singh, S. K. 2011. The role of staff development in the professional development of teachers: Implications for in-service training. South African Journal of Higher Education 25(8): 1626-1638.

Sum, S., M. Saboor and R. Sahaf. 2015. Older people, loneliness and depression. Medicinski Glasnik/ 
Medical Gazette 20(56): 31-42.

Theron, L. and C. Dalzell. 2006. The specific Life Orientation needs of Grade 9 learners in the Vaal Triangle region. South African Journal of Education 26(3): 397-412.

Tlhabane, E. M. 2004. The training need of Life Orientation teachers in the Mabopane District. Unpublished master's dissertation. Pretoria: University of South Africa.

Tshelane, M. 2014. Democratic postgraduate student leadership for sustainable learning environment. South African Journal of Higher Education 28(3): 717-732.

Van Deventer, K. J. 2008. Perceptions of Life Orientation teachers regarding the implementation of the learning area in Grades 8 and 9: A survey in selected Cape high schools. South African Journal for Research in Sport, Physical Education and Recreation 30(2): 131-146.

Van Deventer, K. J. and E. van Niekerk. 2008. Life Orientation in grades R-11: Teachers’ perspectives on the implementation of Life Orientation in selected Western Cape Schools. Unpublished research report. Stellenbosch: Stellenbosch University.

Van Deventer, J. and E. van Niekerk. 2009. Life orientation in the foundation phase (grades R-3): A survey in selected Western Cape primary schools. South African Journal for Research in Sport, Physical Education and Recreation 31(2): 147-162.

Van Deventer, K. J. 2009. Perspectives of teachers on the implementation of Life Orientation in Grades R-11 from selected Western Cape schools. South African Journal of Education 29(1): 127-145.

Vygotsky, L. S. 1978. Mind in society: The development of higher-order psychological processes. Cambridge, MA: Harvard University Press.

Weinert, A. B. 2001. Psychology of career development. In International encyclopedia of social and behavioral sciences, 1471-1476.

Welton, J. 2001. Building capacity to deliver education in South Africa? In Implementing education policy. The South African experience, ed. Y. Sayed and J. Jansen. Cape Town: UCT Press.

Wilmot, M. and D. Naidoo. 2014. 'Keeping things straight': The representation of sexualities in Life Orientation textbooks. Sex Education 14(3): 323-337.

Wood, L. and T. Olivier. 2007. Increasing the self-efficacy beliefs of life orientation teachers: An evaluation. Education as Change 11(1): 161-179.

Yamagata-Lynch, L. C. and M. Haudenschild. 2006. Using activity theory to identify contradictions in teacher professional development. Paper presented at the Annual Meeting of the American Educational Research Association (AERA), San Francisco, CA.

Yin, R. K. 2011. Qualitative research from start to finish. New York: The Guilford Press.

Zemylas, M. 2003. Caring for teacher emotion: Reflections on teacher self-development. Studies in Philosophy and Education 22(2): 103-125.

Zhong, Q. 2006. Curriculum reform in China: Challenges and reflections. Frontiers of education in China 1(3): 370-382. 